\title{
The knowledge versus self-rated confidence of facility birth attendants with respect to maternal and newborn health skills: the experience of Nigerian primary
} healthcare facilities

\section{Oluwaseun Esan ${ }^{1}$, Adesegun Fatusi ${ }^{1}$, Temitope $\mathrm{Ojo}^{2}$}

1. Department of Community Health, Faculty of Clinical Sciences, Obafemi Awolowo University, Ile-Ife, Nigeri

2. Department of Community Health, Obafemi Awolowo University Teaching Hospital, Ile-Ife, Nigeria

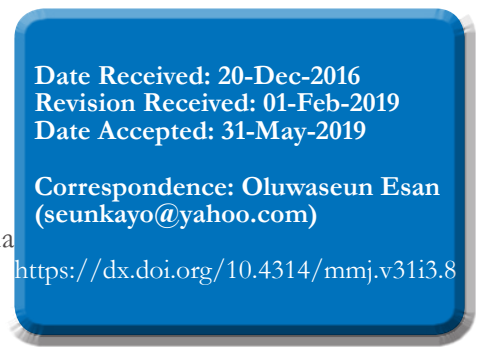

\section{Background}

Abstract

Competent and skilled birth attendants are critical in the reduction of maternal and infant morbidity and mortality at delivery. This study aimed to determine the association between knowledge and self-rated confidence in facility birth attendants affiliated with maternal and neonatal health $(\mathrm{MNH})$ interventions.

Methods

A descriptive cross-sectional study was conducted in 24 primary healthcare facilities in Osun state, Nigeria among 128 consenting facility birth attendants who were selected via a multi-stage sampling technique. Each attendant received a semi-structured intervieweradministered questionnaire. The dependent variables included the respondent's level of knowledge in MNH interventions and their self-rated confidence in MNH skills such as the provision of antenatal care service, normal labour, use of a partograph and the management of obstetric complications and post-partum haemorrhage. Bivariate analysis of factors associated with knowledge and self-rated confidence in MNH skills was performed with statistical significance set at $\mathrm{p}<0.05$.

Results

Only $48(37.5 \%)$ of the respondents had good knowledge of all of the assessed interventions; worse performances were reported with regards to the respondent's knowledge of normal labour and partograph use. However, 96 (75\%) of respondents were confident in performing $75 \%$ of the skills assessed. Our analysis identified two factors that were significantly associated with a good knowledge of MNH skills: the cadre of the birth attendants $(\mathrm{p}<0.001)$ and training in life-saving skills $(\mathrm{p}=0.001)$. The knowledge of our respondents relating to most of the $\mathrm{MNH}$ interventions assessed was not significantly associated with their self-rated confidence in the required skills.

\section{Conclusion}

The confidence of facility birth attendants in MNH skills was not knowledge-based and could frustrate national efforts to reduce maternal and perinatal deaths. We recommend effective and evidence-based training of all cadres of facility birth attendants to ensure that the skills being practiced clinically are based on adequate knowledge.

\section{Key Words}

Birth attendants, knowledge, confidence, maternal and newborn health skills

\section{Introduction}

In 2007, Nigeria embarked on the Integrated Maternal Newborn and Child Health strategy (IMNCH), which aimed to reduce high maternal and neonatal death rates'. Since then, the country has mounted a number of other initiatives in line with the original goal of the IMNCH and to meet the Sustainable Development Goal three (SDG 3). One of the target of the SDG 3 is to reduce Nigeria's maternal mortality ratio (MMR) from 576 in 2013, according to the Nigeria Demographic Health Survey (NDHS) ${ }^{2}$ to $<70$ per 100,000 live births by $2030^{3}$ and also to reduce the neonatal mortality rate from 74 in $2013^{2}$ to 12 per 1000 live births by $2030^{3}$. According to the United Nations Population Fund (UNFPA), Nigeria accounted for $15 \%$ of the world's maternal deaths in 20154.5 . Moreover, with a rate of 70 infant deaths per 1000 live births, Nigeria had the 9th highest infant mortality rate (IMR) in the world ${ }^{6}$ and contributes about $13 \%$ to the global under-five mortality rate (U5MR) ${ }^{7}$. Considering these facts, Nigeria has a long way to go in meeting the SDG 3 targets, hence the need to review the health systems in place in our country.

Global evidence has shown that most maternal and newborn deaths are preventable. The lack of access to skilled care, including emergency obstetric care and quality maternal mortality lifesaving commodities, contribute significantly to Nigeria's high maternal and newborn death rates ${ }^{3,4}$. Indeed, the proportion of births attended by skilled attendants in Nigeria increased from $35.2 \%$ in $2003^{8}$ to $43 \%$ in $2017^{9}$. Furthermore, $<20 \%$ of health facilities offered emergency obstetric care services when surveyed in $2010^{10}$.

The role of skilled care in reducing maternal and newborn deaths has been recognized on a global basis and it is estimated that $16 \%$ to $33 \%$ of maternal deaths could be prevented by the presence of a skilled attendant at birth ${ }^{11}$. Clearly the degree to which the presence of a skilled attendant will impact on MMR will depend on how competent they $a^{11}$. In a previous study, Harvey et al. highlighted that the mere knowledge of a procedure is no guarantee that it can be 
performed correctly ${ }^{12}$ and training does not always guarantee the acquisition of knowledge and ability until knowledge from the training is applied in practice ${ }^{13}$. It is critical that a birth attendant is appropriately 'skilled', which implies the competent use of knowledge ${ }^{11}$. Competency can be viewed as 'possessing skills and knowledge sufficient to comply with predefined clinical standards under enabling and supportive environments ${ }^{12}$. In 1999, the Joint United Nations agencies referred to 'skilled attendants at birth (SBA)' as 'exclusively people with midwifery skills (for example, doctors, midwives, nurses) who have been trained to proficiency in the skills necessary to manage normal deliveries and diagnose, manage or refer complications ${ }^{14}$. A competent health provider is expected to elicit a high level of confidence when faced with emergencies. In this study, we assessed the self-rated confidence of selected respondents to serve as a proxy for their level of competence.

In 2016, the Lancet Maternal Survival Series Steering Group reviewed various reports and studies and noted that despite the pre-service or in-service knowledge received by SBAs, the quality of facility-based maternal services was poor and that the knowledge and skills of health professionals was inadequate ${ }^{15}$. Health centres in Nigeria scored low with regards to technical quality ${ }^{15}$. The Lancet Group also found that the inappropriate management of complications and untimely care in hospitals was common, even for lifethreatening emergencies ${ }^{15}$.

These findings raise a number of questions, including the roles and interplay of knowledge and competence of facility birth attendants (both the skilled clinical care providers and the community health workers based in the health facilities) in managing obstetric complications. These questions formed the basis for our present study. It is believed that in the face of an emergency, a healthcare provider will be prompted to react and would respond based on his or her level of confidence in managing such emergencies ${ }^{16}$. This level of confidence is expected to be based upon their competence, defined as the application of knowledge and experience in managing such cases ${ }^{16}$. If a healthcare provider's knowledge base is inadequate, it presupposes that the healthcare provider may have confidently but wrongly managed the clients over a long period of time. This might explain the persistently high maternal and neonatal mortality indices in Nigeria despite the presence of facility birth attendants at deliveries.

Our study aimed to determine the relationship between the knowledge and self-rated confidence of facility birth attendants in performing maternal and newborn health (MNH) skills and to identify specific factors associated with their knowledge and self-rated confidence.

\section{Methodology \\ Study setting}

The study was descriptive and cross-sectional in design and was conducted in primary healthcare (PHC) facilities in Osun State, South-west Nigeria. The PHC facilities in Nigeria are under the jurisdiction of the Local Government Area (LGA) authority, which is the lowest of the country's three-tier level of governance. A PHC service in each LGA is now also referred to as the Director of Primary Healthcare or Medical Officer of Health for that LGA. There are 30 LGAs and one Area Council in Osun State, spread across six administrative zones (which also constitute the three Senatorial districts). Osun State had 52 secondary health facilities and 693 PHC facilities at the time of this study. Collectively, these facilities featured 1822 healthcare providers involved in maternal and neonatal care services. These providers consist of doctors, nurses, midwives, community health officers and community health extension workers (known as 'facility birth attendants'). These providers constituted the study population for this study. At the time this study was carried out, there were 31 doctors at the primary level of healthcare delivery in Osun state. In line with the 2008 approach of the Nigeria Demographic and Health Survey ${ }^{17}$, the term 'skilled attendant at delivery' included doctors, nurses, nursemidwives and auxiliary nurses.

\section{Selection of study participants}

A total of 128 skilled birth attendants participated in this study. Attendants were selected through a multi-stage sampling technique, with administrative zones as the sampling frame at the first level, and two LGAs selected from each zone using a simple random approach (amounting to 12 LGAs). Next, two PHC facilities were selected per LGA using a simple random sampling technique. The facility birth attendants were also selected per health facility using a simple random sampling technique. These facility birth attendants were categorized into skilled clinical care service providers and community health officers. The group of skilled clinical care providers included physicians, midwives and nurses while the group of community health workers included community health extension workers (CHEWs) and community health officers (CHOs). This classification was based on the initial job description of the health workers involved. Those referred to as being skilled are expected to carry out the core clinical services and require high levels of proficiency in skills to perform in the health facility. In contrast, community health workers were expected to provide support in the community and act as a liaison between health facilities and the community, thus providing preventive health services under supervision. We included all 12 physicians responsible for the selected health facilities in the 12 LGAs as PHC Directors or Medical Officers of Health. Only consenting facility birth attendants were included in this study.

\section{Data collection and management}

A semi-structured questionnaire was used to select facility birth attendants. Trained assistants then assessed their selfrated confidence with regards to antenatal care services, counselling women on how prepared they were for birth and their readiness for complications, the partographic monitoring of labour, immediate newborn care, manual removal of the placenta, by bimanual compression of the uterus, the repair of cervical tears, the repair of first and second degree perineal tears and the management of postpartum haemorrhage. Subsequent sections in the tool then assessed the knowledge of participants with regards to the provision of antenatal care, normal labour and delivery, the partographic monitoring of labour, care of the newborn, and the management of obstetric complications and postpartum haemorrhage. These areas of focus were selected as they represent the basic skills needed to provide antenatal care, normal labour and delivery services and emergency obstetric care services. These skills are crucial in ensuring safe maternal and newborn health outcomes. The instruments used were adapted from the JHPIEGO/ Maternal and Neonatal Health program tool ${ }^{18}$ and the tool used for a previous study of maternal health by Ijadunola et al. ${ }^{10}$. The https://dx.doi.org/10.4314/mmj.v31i3.8 
questionnaires were pre-tested in a PHC facility outside of the study area.

For the questions assessing knowledge, every correct answer earned a score of 1 . The maximum score possible was 62 . We then calculated the sum total of scores and the percentage of scores. The Nigerian University Education Scoring system, as used by Ijadunola et al. in a similar study 10 , was adopted for the present study, in which $\geq 70 \%$ is excellent, $50-69 \%$ is good, $40-49 \%$ is fair and $<40 \%$ is poor. For this study, $\geq 50 \%$ was judged to be good while $<50 \%$ was judged to be poor. When scoring the self-reported level of competence when performing specific MNH skills, 'Very confident' was given a score of 3, 'Not very confident, need more coaching' was given a score of 2, and 'I cannot perform the skill' was given a score of 1 . To obtain a dichotomized response, Not very confident' and 'Cannot perform skill' were recoded as 'Not confident' while 'Very confident' was left as 'Confident'. This is because an inability to perform the skill is believed to also imply a lack of confidence in performing it. All categories of the healthcare providers studied are expected to perform these skills based on their pre-service training and designated job descriptions. Variable age was recoded based on the derived median age.

Data were analysed at the univariate level by determining the frequency distribution, measures of central tendency and dispersion for the socio-demographic characteristics of respondents, their knowledge scores and their perceived competence with regards to the various MNH skills assessed. Bivariate analysis involved the comparison of means among different cadres of healthcare providers, as well as the determination of factors associated with their level of knowledge and confidence in the $\mathrm{MNH}$ skills assessed. We also assessed how their level of knowledge correlated with their level of confidence with regards to these $\mathrm{MNH}$ skills using the chi-square test with the latter as the outcome variable. SPSS statistical software (version 20) was used for all data analysis and statistical significance was set to a p-value $<0.05$.

Ethical approval was obtained from the Research and Ethical Committee of the Obafemi Awolowo University Teaching Hospitals' Complex, Ile-Ife, Osun state. Permission to conduct the study within Osun state primary healthcare facilities was obtained from the Department of Public Health in the Osun State Ministry of Health. Written informed consent was also obtained from the skilled birth attendants themselves and confidentiality of the data provided was assured.

\section{Results}

The mean age ( \pm standard deviation) of our respondents was $37.0 \pm 8.9$ years, with a median age of 35 years and a semi-interquartile range of 3.75 years. We studied 114 $(89.1 \%)$ females and 14 (19.1\%) male skilled birth attendants, with a female to male ratio of 8 to 1 . There was a higher proportion of nurse-midwives $50(39.1 \%)$ studied; these are nurses with an additional qualification in midwifery. Skilled clinical service providers constituted $71.1 \%$ of the study population. The median period of professional experience of the healthcare providers studied was 6 years, with an interquartile range of 4.6 years. Only $41(32.0 \%)$ and 47 $(36.7 \%)$ of the respondents had received training on Life Saving Skills (LSS) or on any other refresher course during the course of their work, respectively. Only $54(43.2 \%)$ of these skilled birth attendants reported using a partograph routinely when managing their clients. The majority of respondents $(103,80.5 \%)$ indicated that 'patient care' takes most of their professional time at work compared with the amount of time they spend on other activities (Table 1).

Table 1: Socio-demographic characteristics of respondents

\begin{tabular}{|c|c|c|}
\hline \multirow{2}{*}{$\begin{array}{l}\text { Variables } \\
\text { Age }\end{array}$} & Frequency $(n=128)$ & Percentage (\%) \\
\hline & & \\
\hline$\leq 35$ years & 65 & 52.4 \\
\hline$>35$ years $)$ & 59 & 47.6 \\
\hline Total & 124 & 100.0 \\
\hline Sex & & \\
\hline Male & 14 & 10.9 \\
\hline Female & 114 & 89.1 \\
\hline Total & 128 & 100.0 \\
\hline Professional type & & \\
\hline Physician & 7 & 5.5 \\
\hline Nurse & 34 & 26.6 \\
\hline Nurse/midwife & 50 & 39.1 \\
\hline Community Health Officer (CHO) & 10 & 7.8 \\
\hline $\begin{array}{l}\text { Community Health Extension } \\
\text { Worker (CHEW) } \\
\text { Total }\end{array}$ & $\begin{array}{c}27 \\
128 \\
\end{array}$ & $\begin{array}{c}21.1 \\
100.0\end{array}$ \\
\hline Professional categories & & \\
\hline $\begin{array}{l}\text { Skilled clinical service providers } \\
\circ \text { Physician } \\
\circ \text { Nurse } \\
\circ \text { Nurse/midwife }\end{array}$ & 91 & 71.1 \\
\hline \begin{tabular}{|l} 
Community service providers \\
$\circ$ Community Health Officers \\
$\circ \quad$ Community Health Extension \\
Workers
\end{tabular} & 37 & 28.9 \\
\hline Total & 128 & $100 / 0$ \\
\hline Years of professional experience & & \\
\hline $\begin{array}{l}<6 \text { years } \\
\geq 7 \text { years } \\
\text { Total }\end{array}$ & $\begin{array}{c}58 \\
59 \\
117\end{array}$ & $\begin{array}{c}49.6 \\
50.4 \\
100.0\end{array}$ \\
\hline $\begin{array}{l}\text { Ever participated in Life Saving } \\
\text { Skills (LSS) course }\end{array}$ & & \\
\hline Yes & 41 & 32.0 \\
\hline No & 87 & 68.0 \\
\hline Total & 128 & \\
\hline Ever had other refresher courses & & \\
\hline Yes & 47 & 36.7 \\
\hline No & 87 & 63.3 \\
\hline Total & 124 & 100.0 \\
\hline $\begin{array}{l}\text { Distribution of professional time } \\
\text { at work }\end{array}$ & & \\
\hline Predominantly patient care & 103 & 80.5 \\
\hline $\begin{array}{l}\text { Predominantly other tasks, besides } \\
\text { patient care }\end{array}$ & 25 & 19.5 \\
\hline Total & 128 & 100.0 \\
\hline
\end{tabular}

Knowledge of skilled birth attendants with regards to selected MNH interventions

Having categorized the level of knowledge into good and poor groups, we found that only $48(37.5 \%)$ of these skilled birth attendants scored above $50 \%$, which represented a good knowledge of all interventions assessed. A higher 
proportion of the respondents had a good knowledge of antenatal care $(78.1 \%)$ and the management of post-partum haemorrhage $(74.2 \%)$. Performances were worse with regards to knowledge relating to normal labour (33.6\%) and use of a partograph in monitoring labour (21.9\%) (Table 2).

Table 2: The performance of facility birth attendants with regards to their knowledge of selected $\mathrm{MNH}$ interventions

\begin{tabular}{|lccc|}
\hline MNH interventions & $\begin{array}{c}\text { Good level of } \\
\text { knowledge }\end{array}$ & $\begin{array}{c}\text { Poor level of } \\
\text { knowledge }\end{array}$ & Total \\
(Frequency)
\end{tabular}

The overall mean percentage score relating to knowledge of all of the maternal and newborn interventions included in our survey was $44.2 \pm 16.9 \%$, with a median score of $43.4 \%$ and a semi-interquartile range of $11.5 \%$. Based on the median percentage scores, knowledge of the management of post-partum haemorrhage received the highest score $(66.7 \%)$, with a semi-interquartile range of $25 \%$. This was closely followed by knowledge of antenatal care with a score of $65 \%$ and a semi-interquartile range of $10 \%$. Knowledge of the use of a partograph showed the lowest median percentage score $(26.7 \%)$ with a semi-interquartile range of $23.3 \%$ (Table 3 ). There was a significant difference between and within the cadres of healthcare providers with regards to the mean scores of their overall knowledge of $\mathrm{MNH}$ interventions (F-test=9.753; $<<0.001)$ and the mean number of skills they were competent in $(\mathrm{F}$-test $=3.417 ; \mathrm{p}=0.011)$. The differences in the means of their overall knowledge of $\mathrm{MNH}$ interventions between and within the groups of skilled birth attendants who had received LSS training and those who had not was also significant (F-test $=8.375$; $\mathrm{p}=0.004)$. However, the differences in the mean number of skills they reported confidence and competence in, both within and between these two categories, were not significant (F-test $=0.181 ; \mathrm{p}=0.672$ ).

\section{Self-rated confidence of healthcare workers with regards to select MNH skills}

More than half of the respondents reported being confident in most of the skills assessed and did not need any further coaching except for partograph utilization (62; 48.4\%), bimanual compression of the uterus $(56 ; 43.8 \%)$ and repair of cervical tears $(51 ; 39.8 \%)$ (Table 4$)$. Only $43(33.6 \%)$ of healthcare providers reported that they were confident in all of the selected MNH skills. However, 96 (75\%) of the healthcare providers reported that they were confident in in at least $9(75 \%)$ of the 12 selected MNH skills.

\section{Factors associated with the overall knowledge score of respondents with regards to $M N H$ interventions}

Only $48(37.5 \%)$ of the respondents scored $\geq 50 \%$ and were therefore judged as having a good knowledge when all of the MNH interventions were assessed collectively. Age was not significantly associated with the level of knowledge for $\mathrm{MNH}$ interventions $(\mathrm{p}=0.124)$. However, several factors were significantly associated with having a good knowledge of all MNH interventions (Table 5), including being a skilled clinical service provider $(\mathrm{p}<0.001)$, in particular, being a physician or a nurse-midwife, being trained in LSS ( $p=0.001)$ and application of partographs in the respondents health facilities $(p=0.013)$.

Table 3: Mean percentage scores of facility birth attendants with regards to their knowledge of selected $\mathrm{MNH}$ interventions

\begin{tabular}{|c|c|c|c|c|c|c|}
\hline Variables & n & Means & $\begin{array}{l}\text { Standard } \\
\text { deviation }\end{array}$ & Median & $\begin{array}{c}\text { Semi- } \\
\text { interquartile } \\
\text { range }\end{array}$ & $\begin{array}{l}\text { Direction of } \\
\text { skewedness }\end{array}$ \\
\hline $\begin{array}{l}\text { Knowledge of } \\
\text { antenatal care }\end{array}$ & 128 & 59.8 & 21.7 & 65.0 & 60.0 & $\begin{array}{l}\text { Negatively } \\
\text { skewed }\end{array}$ \\
\hline $\begin{array}{l}\text { Knowledge of } \\
\text { normal labour } \\
\text { and delivery }\end{array}$ & 128 & 37.6 & 20.2 & 35.0 & 35.0 & $\begin{array}{l}\text { Positively } \\
\text { skewed }\end{array}$ \\
\hline $\begin{array}{l}\text { Knowledge } \\
\text { of immediate } \\
\text { newborn } \\
\text { resuscitation }\end{array}$ & 128 & 48.5 & 18.1 & 50.0 & 50.0 & $\begin{array}{l}\text { Negatively } \\
\text { skewed }\end{array}$ \\
\hline $\begin{array}{l}\text { Knowledge of } \\
\text { the partograph }\end{array}$ & 128 & 29.2 & 28.1 & 26.7 & 23.4 & $\begin{array}{l}\text { Positively } \\
\text { skewed } \\
\end{array}$ \\
\hline $\begin{array}{l}\text { Knowledge } \\
\text { of the } \\
\text { management } \\
\text { of obstetric } \\
\text { complications }\end{array}$ & 128 & 44.7 & 25.7 & 50.0 & 45.0 & $\begin{array}{l}\text { Negatively } \\
\text { skewed }\end{array}$ \\
\hline $\begin{array}{l}\text { Knowledge } \\
\text { of the } \\
\text { management } \\
\text { of post-partum } \\
\text { haemorrhage }\end{array}$ & 128 & 58.5 & 32.8 & 66.7 & 58.3 & $\begin{array}{l}\text { Negatively } \\
\text { skewed }\end{array}$ \\
\hline $\begin{array}{l}\text { Overall } \\
\text { knowledge } \\
\text { of all } \\
\text { interventions }\end{array}$ & 128 & 44.2 & 16.9 & 43.4 & 26.0 & $\begin{array}{l}\text { Normally } \\
\text { distributed }\end{array}$ \\
\hline
\end{tabular}

The manner in which facility birth attendants distributed their professional working time was not significantly associated with them possessing good or bad knowledge of all interventions $(\mathrm{p}=0.274)$. Indeed, a higher proportion of those who spent more time on 'patient care' scored less than $50 \%$ in the overall score relating to knowledge (Table 5).

\section{Factors associated with self-rated confidence in selected MNH skills}

Compared with females, a higher proportion of males rated themselves as being confident in at least $75 \%$ of the skills; however, this finding was not statistically significant $(p=0.515)$. More than $75 \%$ of physicians, nurse-midwives and nurses rated themselves as being confident in $75 \%$ or more of the MNH skills assessed compared with $\mathrm{CHOs}$ and CHEWs; this difference was statistically significant $(p=0.007)$. Therefore, professional types $(p=0.002)$, as well as receiving training in LSS $(\mathrm{p}=0.019)$, were significantly associated with self-rated confidence in at least $9(75 \%)$ of the MNH skills. Other factors, such as age, years of experience, receiving training in LSS, the proportion of professional working time distributed across various assignments, and the 
use of partographs for normal labour, were not significantly associated with self-rated confidence (Table 6).

Table 4: Self-rated level of confidence of respondents in MNH skills

\begin{tabular}{|c|c|c|c|c|}
\hline MNH skills & $\begin{array}{l}\text { Very confident, do } \\
\text { not need coaching }\end{array}$ & $\begin{array}{c}\text { Not very } \\
\text { confident, need } \\
\text { coaching }\end{array}$ & $\begin{array}{l}\text { Not confident, } \\
\text { cannot perform } \\
\text { skill }\end{array}$ & Total \\
\hline & Frequency $(\%)$ & Frequency $(\%)$ & Frequency $(\%)$ & Frequency $(\%)$ \\
\hline Managing antenatal patients & $101(84.4)$ & $13(10.2)$ & $7(5.4)$ & $121(100.0)$ \\
\hline $\begin{array}{l}\text { Counselling pregnant women } \\
\text { on birth preparedness and } \\
\text { complication readiness }\end{array}$ & $105(82.0)$ & $14(10.9)$ & $9(7.0)$ & $128(100.0)$ \\
\hline $\begin{array}{l}\text { Managing normal labour \& } \\
\text { delivery }\end{array}$ & $95(74.2)$ & $21(16.4)$ & $12(9.4)$ & $128(100.0)$ \\
\hline Use of the partograph & $62(48.4)$ & $24(18.8)$ & $42(32.8)$ & $128(100.0)$ \\
\hline $\begin{array}{l}\text { Active management of the } \\
\text { third stage of labour }\end{array}$ & $97(75.8)$ & $17(13.3)$ & $14(10.9)$ & $128(100.0)$ \\
\hline Newborn resuscitation & $88(68.8)$ & $25(19.5)$ & $15(11.7)$ & $128(100.0)$ \\
\hline Post-partum care & $101(78.9)^{\prime}$ & $12(9.4)$ & $15(7.7)$ & $128(100.0)$ \\
\hline $\begin{array}{l}\text { Manual removal of the } \\
\text { placenta }\end{array}$ & $71(55.1)$ & $12(9.4)$ & $15(11.7)$ & $98(100.0)$ \\
\hline $\begin{array}{l}\text { Bimanual compression of the } \\
\text { uterus }\end{array}$ & $56(43.8)$ & $21(16.4)$ & $36(29.1)$ & $113(100.0)$ \\
\hline Repair of cervical tear & $51(39.8)$ & $31(24.2)$ & $46(35.9)$ & $128(100.0)$ \\
\hline $\begin{array}{l}\text { Repair of } 1 \text { st and } 2 \text { nd stage } \\
\text { perineal tear }\end{array}$ & $67(52.3)$ & $30(23.4)$ & $31(24.2)$ & $128(100.0)$ \\
\hline $\begin{array}{l}\text { Management of post-partum } \\
\text { heamorrhage }\end{array}$ & $70(54.7)$ & $25(19.5)$ & $33(25.8)$ & $128(100.0)$ \\
\hline
\end{tabular}

Table 5: Factors associated with the knowledge of respondents with regards to $\mathrm{MNH}$ interventions

\begin{tabular}{|c|c|c|c|c|}
\hline $\begin{array}{l}\text { Independent } \\
\text { variables }\end{array}$ & \begin{tabular}{|l|}
$\begin{array}{l}\text { Good } \\
\text { knowledge }\end{array}$ \\
Freq. $(\%)$
\end{tabular} & 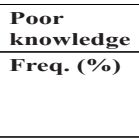 & $\begin{array}{l}\text { Freq. } \\
(\%)\end{array}$ & \begin{tabular}{|l|} 
Test of \\
statistical \\
significance \\
and degrees \\
of freedom \\
(dfs) \\
\end{tabular} \\
\hline $\begin{array}{l}\text { Sex } \\
\text { Male } \\
\text { Female }\end{array}$ & $\begin{array}{r}5(35.7) \\
43(37.7)\end{array}$ & $\begin{array}{r}9(64.3) \\
71(62.3)\end{array}$ & $\begin{array}{l}14 \\
(100.0) \\
114 \\
(100.0)\end{array}$ & $\begin{array}{l}\chi^{2}=0.021 \\
(1) \\
p=0.884\end{array}$ \\
\hline $\begin{array}{l}\text { Age (by median } \\
\text { age of } 35 \text { years) } \\
\leq 35 \text { years } \\
>35 \text { years }\end{array}$ & $\begin{array}{l}21(32.3) \\
27(45.8)\end{array}$ & $\begin{array}{l}44(67.7) \\
32(54.2)\end{array}$ & $\begin{array}{l}65 \\
(100.0) \\
59 \\
(100.0)\end{array}$ & $\begin{array}{l}\chi^{2}=2.360,(1) \\
p=0.124\end{array}$ \\
\hline $\begin{array}{l}\text { Professional type } \\
\begin{array}{l}\text { Physician, Nurse } \\
\text { only, Nurse- } \\
\text { midwife. }\end{array} \\
\text { CHO \&CHEW }\end{array}$ & $\begin{array}{r}43(47.3) \\
5(13.5)\end{array}$ & $\begin{array}{l}48(52.7) \\
32(86.5)\end{array}$ & $\begin{array}{l}91 \\
(100.0) \\
37 \\
(100.0)\end{array}$ & $\begin{array}{l}\chi^{2}=12.776 \\
\text { (1) } \\
p<0.001\end{array}$ \\
\hline $\begin{array}{l}\text { Individual } \\
\text { professional cadres } \\
\text { Physician } \\
\text { Nurse-midwives } \\
\text { Nurse only } \\
\text { CHO } \\
\text { CHEW }\end{array}$ & $\begin{array}{r}5(71.4) \\
31(62.0) \\
7(20.6) \\
2(20.0) \\
3(11.1)\end{array}$ & $\begin{array}{r}2(28.6) \\
19(38.0) \\
27(79.4) \\
8(80.0) \\
24(88.9)\end{array}$ & $\begin{array}{l}7 \\
(100.0) \\
50 \\
(100.0) \\
34 \\
(100.0) \\
10 \\
(100.0) \\
27 \\
(100.0)\end{array}$ & $\begin{array}{l}\mathrm{LR}=31.158, \\
(4) \\
p<0.001\end{array}$ \\
\hline $\begin{array}{l}\text { Years of } \\
\text { professional } \\
\text { experience } \\
\leq 6 \text { years } \\
\geq 7 \text { years } \\
\end{array}$ & $\begin{array}{l}19(32.8) \\
27(45.8)\end{array}$ & $\begin{array}{l}39(67.2) \\
32(54.2)\end{array}$ & $\begin{array}{l}58 \\
(100.0) \\
59 \\
(100.0)\end{array}$ & $\begin{array}{l}\chi^{2}=2.073,(1) \\
p=0.150\end{array}$ \\
\hline $\begin{array}{l}\text { Ever heard of LSS } \\
\text { Yes } \\
\text { No }\end{array}$ & $\begin{array}{l}37(45.1) \\
11(23.9)\end{array}$ & $\begin{array}{l}45(54.9) \\
35(76.1)\end{array}$ & $\begin{array}{l}82 \\
(100.0) \\
46 \\
(100.0)\end{array}$ & $\begin{array}{l}\chi^{2}=5.656,(1) \\
p=0.017\end{array}$ \\
\hline $\begin{array}{l}\text { Ever trained in } \\
\text { LSS } \\
\text { Yes } \\
\text { No }\end{array}$ & $\begin{array}{l}24(58.5) \\
24(27.6)\end{array}$ & $\begin{array}{l}17(41.5) \\
63(72.4)\end{array}$ & $\begin{array}{l}41 \\
(100.0) \\
87 \\
(100.0)\end{array}$ & $\begin{array}{l}\chi^{2}=11.390, \\
(1) \\
p=0.001\end{array}$ \\
\hline $\begin{array}{l}\text { Ever attended any } \\
\text { refresher course } \\
\text { Yes } \\
\text { No }\end{array}$ & $\begin{array}{l}20(42.6) \\
28(34.6)\end{array}$ & $\begin{array}{l}27(57.4) \\
53(65.4)\end{array}$ & $\begin{array}{l}47 \\
(100.0) \\
81 \\
(100.0)\end{array}$ & $\begin{array}{l}\chi^{2}=0.809,(1) \\
p=0.368\end{array}$ \\
\hline
\end{tabular}

Table 6: Factors associated with the self-rated confidence of facility birth attendants in MNH skills

\begin{tabular}{|c|c|c|c|c|}
\hline \multirow[t]{2}{*}{$\begin{array}{l}\text { Independent } \\
\text { variables }\end{array}$} & $\begin{array}{l}\text { Self-rated } \\
\text { confidence } \\
\text { in } \geq 9(75 \%) \\
\text { MNH skills } \\
\end{array}$ & $\begin{array}{l}\text { Self-rated } \\
\text { confidence } \\
\text { in }<9(75 \%) \\
\text { MNH skills } \\
\end{array}$ & Total & \multirow{2}{*}{\begin{tabular}{|l|} 
Test of \\
statistical \\
significance \\
and degrees \\
of freedom \\
(dfs)
\end{tabular}} \\
\hline & Freq. (\%) & Freq. $(\%)$ & Freq. (\%) & \\
\hline $\begin{array}{l}\text { Sex } \\
\text { Male } \\
\text { Female }\end{array}$ & $\begin{array}{l}12(85.7) \\
84(73.7)\end{array}$ & $\begin{array}{r}2(14.3) \\
30(26.3)\end{array}$ & $\begin{array}{r}14(100.0) \\
114(100.0)\end{array}$ & $\begin{array}{l}\text { Fishers exact, } \\
p=0.515\end{array}$ \\
\hline $\begin{array}{l}\text { Age (by median } \\
\text { age of } 35 \text { years) } \\
\leq 35 \text { years } \\
>35 \text { years }\end{array}$ & $\begin{array}{l}49(75.4) \\
44(74.6)\end{array}$ & $\begin{array}{l}16(24.6) \\
15(25.4)\end{array}$ & $\begin{array}{l}65(100.0) \\
59(100.0)\end{array}$ & $\begin{array}{l}\chi^{2}=0.011,(1) \\
p=0.917\end{array}$ \\
\hline $\begin{array}{l}\text { Professional type } \\
\text { Physician; Nurse \& } \\
\text { Nurse-midwife. } \\
\text { CHO \&CHEW }\end{array}$ & $\begin{array}{l}75(82.4) \\
21(56.8)\end{array}$ & $\begin{array}{l}16(17.6) \\
1643.2)\end{array}$ & $\begin{array}{l}91(100.0) \\
37(100.0)\end{array}$ & $\begin{array}{l}\chi^{2}=9.238,(1) \\
p=0.002\end{array}$ \\
\hline $\begin{array}{l}\text { Individual } \\
\text { professional cadres } \\
\text { Physician } \\
\text { Nurse-midwives } \\
\text { Nurse only } \\
\text { CHO } \\
\text { CHEW }\end{array}$ & $\begin{array}{r}6(85.7) \\
43(86.0) \\
26(76.5) \\
3(30.0) \\
18(66.7)\end{array}$ & $\begin{array}{l}1(14.3) \\
7(14.0) \\
8(23.5) \\
7(70.0) \\
9(33.3)\end{array}$ & $\begin{array}{r}7(100.0) \\
50(100.0) \\
34(100.0) \\
10(100.0) \\
27(100.0)\end{array}$ & $\begin{array}{l}\mathrm{LR}=14.030, \\
(4) \\
p=0.007\end{array}$ \\
\hline $\begin{array}{l}\text { Years of } \\
\text { professional } \\
\text { experience } \\
\leq 6 \text { years } \\
\geq 7 \text { years }\end{array}$ & $\begin{array}{l}44(75.9) \\
44(74.6)\end{array}$ & $\begin{array}{l}14(24.1) \\
15(25.4)\end{array}$ & $\begin{array}{l}58(100.0) \\
59(100.0)\end{array}$ & $\begin{array}{l}\chi^{2}=0.026,(1) \\
p=0.872\end{array}$ \\
\hline $\begin{array}{l}\text { Ever heard of LSS } \\
\text { Yes } \\
\text { No }\end{array}$ & $\begin{array}{l}67(81.7) \\
29(63.0)\end{array}$ & $\begin{array}{l}15(18.3) \\
17(37.0)\end{array}$ & $\begin{array}{l}82(100.0) \\
46(100.0)\end{array}$ & $\begin{array}{l}\chi^{2}=5.475,(1) \\
p=0.019\end{array}$ \\
\hline $\begin{array}{l}\text { Ever trained in } \\
\text { LSS } \\
\text { Yes } \\
\text { No } \\
\end{array}$ & $\begin{array}{l}31(75.6) \\
65(74.7)\end{array}$ & $\begin{array}{l}10(24.4) \\
22(25.3)\end{array}$ & $\begin{array}{l}41(100.0) \\
87(100.0)\end{array}$ & $\begin{array}{l}\chi^{2}=0.012,(1) \\
p=0.913\end{array}$ \\
\hline $\begin{array}{l}\text { Ever attended any } \\
\text { refresher course } \\
\text { Yes } \\
\text { No }\end{array}$ & $\begin{array}{l}39(83.0) \\
57(70.4)\end{array}$ & $\begin{array}{r}8(17.0) \\
24(29.6)\end{array}$ & $\begin{array}{l}47(100.0) \\
81(100.0)\end{array}$ & $\begin{array}{l}\chi^{2}=2.522,(1) \\
p=0.112\end{array}$ \\
\hline $\begin{array}{l}\text { Provider routinely } \\
\text { use partograph } \\
\text { Yes } \\
\text { No }\end{array}$ & $\begin{array}{l}41(75.9) \\
52(73.2)\end{array}$ & $\begin{array}{l}13(24.1) \\
19(26.8)\end{array}$ & $\begin{array}{l}54(100.0) \\
71(100.0)\end{array}$ & $\begin{array}{l}\chi^{2}=0.116,(1) \\
p=0.733\end{array}$ \\
\hline
\end{tabular}

The association between the knowledge of bealth workers with regards to MNH interventions and their self-rated confidence in the required $M N H$ skills

Knowledge scores for each of the interventions were compared with MNH skills that were related to and expected to be dependent on this knowledge. Findings revealed that having a good or poor knowledge of most of the interventions assessed was not significantly associated with their perceived confidence in the required skills. This, however, was not the case for their knowledge assessment, for 'normal labour' and 'use of a partograph' as having good knowledge in these areas was significantly associated with confidence in the partographic monitoring of labour $(\mathrm{p}=0.021$ and $\mathrm{p}<0.001$, respectively) (Table 7).

The knowledge of facility birth attendants with regards to the management of obstetric complications was assessed and compared with their self-rated confidence for the required skills to prevent post-partum haemorrhage. There was no significant association between the respondents' knowledge of managing obstetric complications and their self-rated confidence in each of the skills required to repair first- and second-stage perineal tears $(\mathrm{p}=0.635)$, repairing cervical tears $(p=0.657)$, bimanual compression of the uterus $(p=0.424)$ and manual removal of the placenta in cases of placenta retention $(\mathrm{p}=0.813)$. 


\section{Table 6 Cont...}

\begin{tabular}{|l|l|l|l|l|}
\hline $\begin{array}{l}\text { Institution have } \\
\text { WHanaging obstetric } \\
\text { complications } \\
\text { Yes }\end{array}$ & $28(71.8)$ & $11(28.2)$ & $39(100.0)$ & $\chi^{2}=0.307,(1)$ \\
No & $68(76.4)$ & $21(23.6)$ & $89(100.0)$ & $p=0.579$ \\
\hline $\begin{array}{l}\text { Institution has } \\
\text { other guidelines/ } \\
\text { protocol for } \\
\text { managing } \\
\text { complications }\end{array}$ & $16(80.0)$ & $4(20.0)$ & $20(100.0)$ & $\chi^{2}=0.340,(1)$ \\
$\begin{array}{l}\text { Yes } \\
\text { No }\end{array}$ & $79(73.8)$ & $28(26.2)$ & $107(100.0)$ & $p=0.560$ \\
\hline $\begin{array}{l}\text { Type of work } \\
\text { taking highest } \\
\text { proportion of time } \\
\text { Patient care }\end{array}$ & $78(75.7)$ & $25(24.3)$ & $103(100.0)$ & $\chi^{2}=0.149,(1)$ \\
$\begin{array}{l}\text { Others aside from } \\
\text { patient care }\end{array}$ & $18(72.0)$ & $7(28.0)$ & $25(100.0)$ & $p=0.699$ \\
\hline $\begin{array}{l}\text { Knowledge } \\
\text { of healthcare } \\
\text { provider on } \\
\text { all MNH } \\
\text { interventions } \\
\text { studied }\end{array}$ & $40(83.3)$ & $8(16.7)$ & $48(100.0)$ & $\chi^{2}=2.844,(1)$ \\
$\begin{array}{l}\text { Good } \\
\text { Poor }\end{array}$ & $56(70.0)$ & $24(30.0)$ & $80(100.0)$ & $p=0.092$ \\
\hline
\end{tabular}

Table 7: Association between the knowledge and selfrated confidence of respondents in antenatal, normal labour and newborn care skills

\begin{tabular}{|c|c|c|c|c|}
\hline \multirow[t]{2}{*}{$\begin{array}{l}\text { Independent } \\
\text { variables }\end{array}$} & $\begin{array}{l}\text { Confident } \\
\text { in } \\
\text { performing } \\
\text { skills } \\
\end{array}$ & $\begin{array}{l}\text { Not } \\
\text { confident in } \\
\text { performing } \\
\text { skills } \\
\end{array}$ & Total & \multirow{2}{*}{$\begin{array}{l}\text { Test of } \\
\text { statistical } \\
\text { significance, } \\
\text { degrees of } \\
\text { freedom (dfs) } \\
\text { and } p \text {-value }\end{array}$} \\
\hline & Freq. (\%) & Freq. (\%) & $\begin{array}{l}\text { Freq- } \\
(\%)\end{array}$ & \\
\hline \multicolumn{5}{|c|}{ Self-rated confidence in managing antenatal patients } \\
\hline $\begin{array}{l}\text { Knowledge of } \\
\text { antenatal care } \\
\text { Good } \\
\text { Poor }\end{array}$ & $\begin{array}{l}86(86.0) \\
22(78.6)\end{array}$ & $\begin{array}{r}14(14.0) \\
6(21.4)\end{array}$ & $\begin{array}{l}100 \\
(100.0) \\
28 \\
(100.0)\end{array}$ & $\begin{array}{l}\chi^{2}=0.916,(1) \\
p=0.339\end{array}$ \\
\hline \multicolumn{5}{|c|}{$\begin{array}{l}\text { Self-rated confidence in counselling on birth preparedness and } \\
\text { complication readiness }\end{array}$} \\
\hline $\begin{array}{l}\text { Knowledge of } \\
\text { antenatal care } \\
\text { Good } \\
\text { Poor }\end{array}$ & $\begin{array}{l}85(85.0) \\
20(71.4)\end{array}$ & $\begin{array}{r}15(15.0) \\
8(28.6)\end{array}$ & $\begin{array}{l}100 \\
(100.0) \\
28 \\
(100.0)\end{array}$ & $\begin{array}{l}\chi^{2}=2.733,(1) \\
p=0.098\end{array}$ \\
\hline \multicolumn{5}{|c|}{$\begin{array}{l}\text { Self-rated confidence in normal labour, childbirth and immediate } \\
\text { newborn care }\end{array}$} \\
\hline $\begin{array}{l}\text { Knowledge of } \\
\text { normal labour } \\
\text { Good } \\
\text { Poor }\end{array}$ & $\begin{array}{l}33(76.7) \\
62(72.9)\end{array}$ & $\begin{array}{l}10(23.3) \\
23(27.1)\end{array}$ & $\begin{array}{l}43 \\
(100.0) \\
85 \\
(100.0)\end{array}$ & $\begin{array}{l}\chi^{2}=0.216,(1) \\
p=0.642\end{array}$ \\
\hline \multicolumn{5}{|c|}{ Self-rated confidence in the use of the partograph } \\
\hline $\begin{array}{l}\text { Knowledge of } \\
\text { normal labour } \\
\text { Good } \\
\text { Poor }\end{array}$ & $\begin{array}{l}27(62.8) \\
35(41.2)\end{array}$ & $\begin{array}{l}16(37.2) \\
50(58.8)\end{array}$ & $\begin{array}{l}43 \\
(100.0) \\
85 \\
(100.0) \\
\end{array}$ & $\begin{array}{l}\chi^{2}=5.341,(1) \\
p=0.021\end{array}$ \\
\hline \multicolumn{5}{|c|}{$\begin{array}{l}\text { Self-rated confidence in the active management of the third stage of } \\
\text { labour }\end{array}$} \\
\hline $\begin{array}{l}\text { Knowledge of } \\
\text { normal labour } \\
\text { Good } \\
\text { Poor }\end{array}$ & $\begin{array}{l}32(74.4) \\
65(76.5)\end{array}$ & $\begin{array}{l}11(25.6) \\
20(23.5)\end{array}$ & $\begin{array}{l}43 \\
(100.0) \\
85 \\
(100.0)\end{array}$ & $\begin{array}{l}\chi^{2}=0.066,(1) \\
p=0.798\end{array}$ \\
\hline \multicolumn{5}{|c|}{ Self-rated confidence in the use of a partograph for monitoring labour } \\
\hline $\begin{array}{l}\text { Knowledge } \\
\text { of the use of } \\
\text { partograph } \\
\text { Good } \\
\text { Poor }\end{array}$ & $\begin{array}{l}23(82.1) \\
39(30.0)\end{array}$ & $\begin{array}{r}5(17.9) \\
61(61.0)\end{array}$ & $\begin{array}{l}28 \\
(1000.0) \\
100 \\
(100.0) \\
\end{array}$ & $\begin{array}{l}\chi^{2}=16.302,(1) \\
p<0.001\end{array}$ \\
\hline \multicolumn{5}{|c|}{ Self-rated confidence in newborn resuscitation } \\
\hline $\begin{array}{l}\text { Knowledge of } \\
\text { newborn care } \\
\text { Good } \\
\text { Poor }\end{array}$ & $\begin{array}{l}54(68.4) \\
34(69.4)\end{array}$ & $\begin{array}{l}25(31.6) \\
15(30.6)\end{array}$ & $\begin{array}{l}79 \\
(100.0) \\
49 \\
(100.0) \\
\end{array}$ & $\begin{array}{l}\chi^{2}=0.015,(1) \\
p=0.902\end{array}$ \\
\hline \multicolumn{5}{|c|}{ Self-rated confidence in the management of the immediate post-partum } \\
\hline $\begin{array}{l}\text { Knowledge of } \\
\text { newborn care } \\
\text { Good } \\
\text { Poor }\end{array}$ & $\begin{array}{l}64(81.0) \\
37(75.5)\end{array}$ & $\begin{array}{l}15(19.0) \\
12(24.5)\end{array}$ & $\begin{array}{l}79 \\
(100.0) \\
49 \\
(100.0)\end{array}$ & $\begin{aligned} \chi^{2} & =0.550,(1) \\
p & =0.458\end{aligned}$ \\
\hline
\end{tabular}

Table 8: Association between knowledge and self-rated confidence of respondents in the management of obstetric complications and post-partum haemorrhage

\begin{tabular}{|c|c|c|c|c|}
\hline \multirow[t]{2}{*}{$\begin{array}{l}\text { Independent } \\
\text { variables }\end{array}$} & $\begin{array}{l}\text { Confident in } \\
\text { performing } \\
\text { skill }\end{array}$ & $\begin{array}{l}\text { Not } \\
\text { confident } \\
\text { in } \\
\text { performing } \\
\text { skill } \\
\end{array}$ & Total & \multirow{2}{*}{$\begin{array}{l}\text { Test of } \\
\text { statistical } \\
\text { significance, } \\
\text { degrees of } \\
\text { freedom } \\
\text { (df) and } \\
\text { P-value }\end{array}$} \\
\hline & Freq. (\%) & Freq. $(\%)$ & \begin{tabular}{|l|} 
Freq. \\
$(\%)$
\end{tabular} & \\
\hline \multicolumn{5}{|c|}{ Self-rated confidence in performing manual removal of the placenta } \\
\hline \multicolumn{5}{|c|}{ 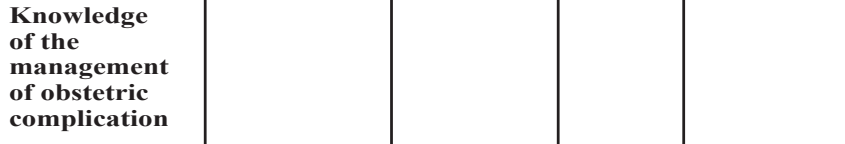 } \\
\hline Good & $35(53.8)$ & $30(46.2)$ & $\begin{array}{l}65 \\
(100.0)\end{array}$ & $\chi^{2}=0.141,(1)$ \\
\hline Poor & $36(57.1)$ & 27(42.9) & $\begin{array}{l}63 \\
(100.0)\end{array}$ & $p=0.708$ \\
\hline
\end{tabular}

Self-rated confidence in the repair of $1 \mathrm{st}$ and 2 nd stage perineal tear

Knowledge

of the

management

of obstetric

complications

Good

\begin{tabular}{l|l|l|l}
$36(55.4)$ & $29(44.6)$ & $\begin{array}{l}65 \\
(100.0)\end{array}$ & $\chi^{2}=0.490,(1)$ \\
$31(49.2)$ & $32(50.8)$ & $\begin{array}{l}63 \\
(100.0)\end{array}$ & $p=0.484$ \\
& &
\end{tabular}

Poor

Self-rated confidence in repair of cervical tear

Knowledge

of the

management

of obstetric

complications

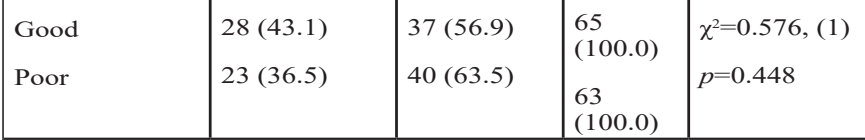

Self-rated confidence in performing bimanual compression of the uterus

Knowledge

of the

management

of obstetric

complication

Good

Poor

$28(43.1)$

$37(56.9) \quad 65$

$28(44.4)$

$35(55.6)$

(100.0) $\quad \chi^{2}=0.024,(1)$

Self-rated confidence in the management of post-partum

haemorrhage

Knowledge

of the

management

of obstetric

complications

Good

\begin{tabular}{l|l|l|l}
$38(58.5)$ & $27(41.5)$ & 65 & $\chi^{2}=0.759,(1)$
\end{tabular}

Poor

$32(50.8)$

$31(49.2)$

63

$p=0.384$

Self-rated confidence in the management of post-partum

haemorrhage

Knowledge

of the

management

of post-partum

haemorrhage

Good

17

Poor

17 (51.5)

$42(44.2)$

95

16 (48.5)

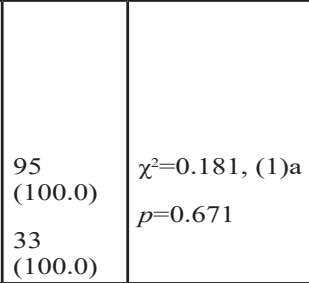

The knowledge of respondents with regards to the management of post-partum haemorrhage was not significantly associated with how confident they were in the clinical management of post-partum haemorrhage $(\mathrm{p}=0.196)$ (Table 8). Table 9 shows how facility birth attendants (categorized by professional type) fared when their overall knowledge of $\mathrm{MNH}$ interventions was compared with their self-rated confidence for selected $\mathrm{MNH}$ 
skills. A high proportion of physicians, nurses, and nurses with dual qualifications as midwives who rated themselves as either good or poor in terms of their knowledge rated themselves as very confident with regards to the selected MNH skills. The CHEWs had a much higher proportion of those who performed poorly but rated themselves as very confident in the MNH skills. The only exceptions to these were the CHOs. From these findings it was evident that there were no statistically significant associations between the knowledge of facility birth attendants with regards to selected MNH interventions by professional type and their self-rated confidence in the performance required for $\mathrm{MNH}$ skills (Table 9).

Table 9: The professional type of respondents and the association between overall knowledge and self-rated confidence in MNH skills

\begin{tabular}{|c|c|c|c|c|}
\hline \multirow[t]{2}{*}{$\begin{array}{l}\text { Professional types } \\
\text { and knowledge } \\
\text { performance }\end{array}$} & $\begin{array}{l}\text { Self-rated } \\
\text { confidence } \\
\text { in } \geq 9(75 \%) \\
\text { MNH skills }\end{array}$ & $\begin{array}{l}\text { Self-rated } \\
\text { confidence } \\
\text { in }<9 \\
(75 \%) \\
\text { MNH skills } \\
\end{array}$ & Total & \multirow[t]{2}{*}{$\begin{array}{l}\text { Test of } \\
\text { statistical } \\
\text { significance } \\
\text { and degrees } \\
\text { of freedom } \\
\text { (dfs) }\end{array}$} \\
\hline & Freq. (\%) & Freq. (\%) & Freq. (\%) & \\
\hline $\begin{array}{l}\text { Physicians } \\
\text { Good knowledge } \\
\text { Poor Knowledge }\end{array}$ & $\begin{array}{l}4(80.0) \\
2(100.0)\end{array}$ & $\begin{array}{l}1(20.0) \\
0(0.0)\end{array}$ & $\begin{array}{l}5(100.0) \\
2(100.0)\end{array}$ & $\begin{array}{l}\text { Fishers } \\
\text { exact, } \\
p=1.000\end{array}$ \\
\hline $\begin{array}{l}\text { Nurse-midwives } \\
\text { Good knowledge } \\
\text { Poor Knowledge }\end{array}$ & $\begin{array}{l}29(93.5) \\
14(73.7)\end{array}$ & $\begin{array}{l}2(6.5) \\
5(26.3)\end{array}$ & $\begin{array}{l}31(100.0) \\
19(100.0)\end{array}$ & $\begin{array}{l}\text { Fishers } \\
\text { exact, } \\
p=0.089\end{array}$ \\
\hline $\begin{array}{l}\text { Nurse only } \\
\text { Good knowledge } \\
\text { Poor Knowledge } \\
\end{array}$ & $\begin{array}{l}5(71.4) \\
21(77.8)\end{array}$ & $\begin{array}{l}2(28.6) \\
6(22.2)\end{array}$ & $\begin{array}{l}7(100.0) \\
27(100.0)\end{array}$ & $\begin{array}{l}\text { Fishers } \\
\text { exact, } \\
p=1.000\end{array}$ \\
\hline $\begin{array}{l}\text { Community Health } \\
\text { Officers } \\
\text { Good knowledge } \\
\text { Poor Knowledge } \\
\end{array}$ & $\begin{array}{l}1(50.0) \\
2(25.0)\end{array}$ & $\begin{array}{l}1(50.0) \\
6(75.0)\end{array}$ & $\begin{array}{l}2(100.0) \\
8(100.0)\end{array}$ & $\begin{array}{l}\text { Fishers } \\
\text { exact, } \\
p=1.000\end{array}$ \\
\hline $\begin{array}{l}\text { Community Health } \\
\text { Extension } \\
\text { Workers } \\
\text { Good knowledge } \\
\text { Poor Knowledge } \\
\end{array}$ & $\begin{array}{l}1(33.3) \\
17(70.8)\end{array}$ & $\begin{array}{l}2(66.7) \\
7(29.2)\end{array}$ & $\begin{array}{l}3(100.0) \\
24(100.0)\end{array}$ & $\begin{array}{l}\text { Fishers } \\
\text { exact, } \\
p=0.250\end{array}$ \\
\hline $\begin{array}{l}\text { All facility birth } \\
\text { attendants } \\
\text { Good knowledge } \\
\text { Poor Knowledge }\end{array}$ & $\begin{array}{l}40(83.3) \\
56(70.0)\end{array}$ & $\begin{array}{r}8(16.7) \\
24(30.0)\end{array}$ & $\begin{array}{l}48(100.0) \\
80(100.0)\end{array}$ & $\begin{array}{l}\chi^{2}=2.844,(1) \\
p=0.092\end{array}$ \\
\hline
\end{tabular}

\section{Discussion}

Skilled care at delivery has been proven to be a key intervention for reducing maternal and neonatal morbidities and mortalities ${ }^{19}$. The need to ensure that healthcare providers have adequate knowledge of managing $\mathrm{MNH}$ issues with the ease of translating this knowledge into a truly competent clinical practice is critical. This study set out to determine if the self-rated confidence reported by facility birth attendants in maternal and newborn care was based upon knowledge or not. Our findings showed that the proportion of skilled birth attendants who had good knowledge of all interventions when assessed overall was disturbingly low. This was the same for most of the specific interventions, particularly with regards to knowledge on attending to normal labour and delivery $(35 \%)$ and their use of the partograph to monitor labour (23.4\%).

Similarly, Oladapo et al. $^{20}$ assessed the knowledge of healthcare providers in peripheral primary health facilities and delivery units in one of the states in Nigeria and found that only $54.5 \%$ of their respondents were aware of a partograph and only $28.2 \%$ had good knowledge of the partograph. This trend, observed in 2006, persisted through to 2010 when Fawole et al. further revealed that only $37.3 \%$ of healthcare providers could correctly mention at least one component of the partograph ${ }^{21,22}$. This performance, as observed by Fawole et al., was worse for healthcare providers in primary and secondary healthcare facilities in Southwest Nigeria, a study population that was similar to the one investigated in our current study ${ }^{21}$. The poor knowledge of skilled birth attendants with regards to the partographic monitoring of labour may have contributed to the findings of Bulatao et al. in 2003 who rated maternal health services using the maternal and neonatal program index (MNPI) in 49 developing countries ${ }^{23}$. These authors concluded that a trained attendant at delivery did not significantly contribute to a reduction in maternal mortality.

Interestingly, the healthcare providers assessed in our present study perceived that they were confident in most of the skills assessed that were needed for the MNH interventions studied. However, a higher proportion of our respondents made an exception to the use of the partograph for normal labour and delivery and the prevention of postpartum haemorrhage with the repair of cervical tears and the bimanual compression of the uterus. This further shows that there is a gap in knowledge and confidence with regards to the use of the partograph in particular.

The skilled care providers (doctors, nurses, and midwives) performed significantly better in terms of their knowledge of the interventions assessed. This finding is similar to that obtained by Harvey et al. in 2007 who sought to identify whether skilled birth attendants were truly skilled. The physicians and nurses performed better in their knowledge assessment compared to the nursing auxiliaries ${ }^{12}$. However, this finding was in stark contrast to the findings of Ariff et al. in which medical officers in Pakistan performed poorly in their knowledge of maternal, newborn and child health compared to the community health workers and nurses assessed ${ }^{24}$.

Also, having heard about the training for LSS for maternal and neonatal health or ever being trained on it were associated with a better performance in the overall knowledge for all interventions. The LSS course trains birth attendants to manage obstetric emergencies. Unfortunately, this course is not delivered regularly and very few facility birth attendants have ever been exposed to it. The training and retraining of facility birth attendants on these skills is therefore critical in achieving a reduction in maternal and neonatal mortality rates. However, an effective model for conducting effective training either as offsite, that is, outside the healthcare provider's organization or onsite, such as on the job training, will need to be ascertained in further studies.

Unsurprisingly, more physicians and nurse-midwives reported that they were confident in at least $75 \%$ of the MNH skills assessed compared with the other cadres of health professionals interviewed. Consequently, the capacity of these health professional cadres needs to be built further in order to enhance their confidence, as they are the personnel that are most commonly available, especially in rural communities providing maternal and neonatal care. Interestingly, even hearing about the LSS course was also significantly associated with the self-rated confidence of respondents in at least $75 \%$ of the skills, whereas receiving 
training on the LSS was not. The reasons underlying this observation were not explored.

The performance of respondents on their overall knowledge of interventions in all categories of facility birth attendants was compared with their self-rated confidence in $\mathrm{MNH}$ skills. A higher proportion of the populations who performed well, and those who performed poorly in terms of their knowledge reported that they were confident in at least $75 \%$ of the MNH skills assessed. This clearly shows that their self-rated confidence for these skills was not based upon their knowledge.

In order to investigate further, we compared our respondents' knowledge of specific MNH interventions with the specific skills required by these interventions. Both those who performed well and those who performed poorly in the knowledge of antenatal care, normal labour and newborn care reported that they were confident in the skills required. However, the use of the partograph was a skill in which a high proportion of the facility birth attendants showed a significant weakness, both in their knowledge scores and in their self-rated confidence. Collectively, our data indicate that knowledge of obstetric complications was not significantly associated with self-rated confidence in terms of the skills needed to prevent or manage obstetric complications or post-partum haemorrhage. These findings reiterate that the perceived confidence of facility birth attendants in skills needed to manage their clients is not necessarily based on an adequate knowledge of these skills.

\section{Conclusion}

The proportion of facility birth attendants with a good knowledge of all MNH interventions was very low and was particularly poor with regards to knowledge of managing normal labour and the partographic monitoring of labour. Furthermore, a high proportion of respondents with good or poor knowledge of these interventions reported that they were confident in the skills required and that they needed no further coaching. The professional cadre of skilled birth attendant involved, and whether they had ever heard or had ever been trained in LSS, were significantly associated with their level of knowledge for MNH interventions. The professional cadre of skilled birth attendant, as well as if they had ever heard about the LSS course, were significantly associated with their self-rated confidence in at least nine of the $\mathrm{MNH}$ skills assessed.

Therefore, we recommend that the effective capacity of all cadres of facility birth attendants should be enhanced for MNH skills. There is a clear need for more objective assessments of the competence of facility birth attendants. This will assist healthcare providers in providing a more accurate rating of their confidence. Where gaps are identified, an effective and evidence-based training model should be developed and adopted to ensure that the skills being practiced clinically are based on adequate knowledge. It is expected that these practices will enhance the MNH skills of facility birth attendants and lead to an improvement in maternal and child health indices, both in Nigeria and beyond.

\section{Funding}

No funding was received for this research.

\section{Availability of data and materials}

The dataset and survey tool is available from the corresponding author and can be shared on request.

\section{Ethical considerations}

Ethical approval was obtained from the Research and Ethical committee of the Obafemi Awolowo University Teaching Hospitals' Complex, Ile- Ife, Osun state. Permission to conduct the study at the Osun state primary healthcare facilities was obtained from the Department of Public Health in the Osun State Ministry of Health. Written informed consent was also obtained from the skilled birth attendants themselves and confidentiality of the data provided was assured.

\section{Authors' contributions}

$\mathrm{OE}$ and $\mathrm{AF}$ designed the study. $\mathrm{OE}$ coordinated the data collection, analysed the data and wrote the first draft of the manuscript. AF and TO reviewed and contributed to the manuscript. All authors contributed to the final manuscript and approved its submission for publication.

\section{Competing interests}

The authors declare that they have no competing interests.

\section{References}

1. Federal Ministry of Health (NG). Integrated Maternal, Newborn and Child Health Strategy [Internet]. [Abuja, Family Health Division (NG); 2007 [cited 2018 Jun 12]. 76 p. Available from: http://www.mamaye. org/en/evidence/integrated-maternal-newborn-and-child-healthstrategy-nigeria.

2. National Population Commission (NPC) [NG] and ICF International. Nigeria Demographic and Health Survey 2013 [Internet]. Abuja, Nigeria, and Rockville, MD, USA; 2014 [cited 2017 Jun 12]. Available from: https://dhsprogram.com/pubs/pdf/FR293/FR293.pdf.

3. United Nations. The Sustainable Development Goals Report [Internet]. New York, USA; 2017 [cited 2019 Feb 20]. 60 p. Available from: https://unstats.un.org/sdgs.

4. Fapohunda BM, Orobaton NG. When women deliver with no one present in Nigeria: who, what, where and so what? PLoS One. 2013;8(7): e69569.

5. WHO, UNICEF, UNFPA, World Bank Group, UNPD. Trends in Maternal Mortality: 1990 to 2015 - Estimates by WHO, UNICEF, UNFPA, World Bank Group and the United Nations Population Division [Internet]. Geneva, Switzerland; 2015 [cited 2018 Mar 23]. Available from: http://whqlibdoc.who.int/publications/2010/9789241500265_ eng.pdf.

6. United Nations, Department of Economic and Social Affairs, Population Division. World Mortality 2017: Data Booklet [Internet]. New York; 2017 [cited 2018 Mar 12]. Available from: https://esa. un.org/unpd/wpp/Download/Standard/Mortality/.

7. Bustreo F. World Health Organization Media Center New data show child mortality rates falling faster than ever. WHO, UNICEF, World Bank Group, UN-DESA Population Division joint news release [Internet]; 2014 [cited 2015 Jul 27]. Available from: http://wwwwhoint/ mediacentre/news/releases/2014/child_mortality_estimates/en/.

8. World Health Organization. Proportion of births attended by a skilled attendant - 2007 updates Factsheet [Internet]. Geneva, Switzerland; 2015 [cited 2019 Jan 31]. Available from: https://apps.who.int/iris/ bitstream/handle/10665/69949/WHO_RHR_07.16_eng.pdf;jsessionid =D2620CA0EC5DA54C491C8F96A8BF21FF?sequence $=1$. 
9. The World Bank Group. Births attended by skilled health staff ( $\%$ of total) [Internet]. The World Bank Data; 2019 [cited 2019 Jan 31]. Available from: https://data.worldbank.org/indicator/SH.STA.BRTC. ZS.

10. Ijadunola KT, Ijadunola MY, Esimai OA, Abiona TC. New paradigm old thinking: The case for emergency obstetric care in the prevention of maternal mortality in Nigeria. BMCWomens Heal. [Internet]; 2010;10:6. DOI: 10.1186/1472-6874-10-6. Available from: http://www. biomedcentral.com/1472-6874/10/6\%0ARESEARCH

11. Graham WJ, Bell JS, Bullough CHW. Can skilled attendance at delivery reduce maternal mortality in developing countries? Stud HSO\&P [Internet]; 2001 [cited 2015 Sep 10];17:97-129. Available from: http://193.190.239.98/bitstream/handle/10390/2655/2001shsop0097. pdf?sequence $=2$

12. Harvey SA, Wong C, Mccaw-binns A, Sandino I, Urbina L. Are skilled birth attendants really skilled? A measurement method, some disturbing results and a potential way forward. Bull World Health Organ. [Internet]; 2007 [cited 2015 Sep 10];85:783-790. Available from: https:/www.scielosp.org/article/bwho/2007.v85n10/783-790/

13. Boulet G. The difference between knowledge and skills: knowing does not make you skilled [Internet]. eLearning Industry; 2015 [cited 2018 Dec 3]. Available from: https://elearningindustry.com/differencebetween-knowledge-and-skills-knowing-not-make-skilled

14. World Health Organization, International Confederation of Midwives, Fédération Internationale de Gynécologie et d'Obstétrique. Making pregnancy safer: the critical role of the skilled attendant: a joint statement by WHO, ICM and FIGO [Internet]. Geneva, Switzerland; 2004 [cited 2015 Sep 10]. 18 p. Available from: http://www.who.int/ iris/handle/10665/42955

15. Koblinsky M, Matthews Z, Hussein J, Mavalankar D, Mridha MK, Anwar I, et al. Going to scale with professional skilled care. Lancet. 2006;368(9544):1377-86.

16. Kak N, Burkhalter B, Cooper M. Measuring the Competence of Healthcare Providers [Internet]. Operations Research Issue Paper 2(1). Bethesda, MD Published for the U.S. Agency for International Development (USAID) by the Quality Assurance (QA) Project; 2001 [cited 2017 Jan 23]. Available from: https://www.usaidassist.org/sites/ assist/files/measuring_the_competence_of_hc_providers_qap_2001. pdf

17. National Population Commission (NPC) [Nigeria] and ICF Macro. Nigeria Demographic and Health Survey 2008 [Internet]. Abuja, Nigeria; 2009 [cited 2015 Sep 23]. Available from: https://www. dhsprogram.com/pubs/pdf/FR222/FR222.pdf

18. JHPIEGO. Guidelines for Assessment of Skilled Providers after Training in Maternal and Newborn Healthcare [Internet]. Blouse A, editor. Baltimore, MD, United States of America: JHPIEGO; 2004 [cited 2009 May 2]. 1-134 p. Available from: http://resources.jhpiego. org/resources/guidelines-assessment-skilled-providers-after-trainingmaternal-and-newborn-healthcare

19. MacDonald M, Starrs A. Skilled Care During Childbirth [Internet]. New York, NY, USA: Family Care International Inc.; 2002 [cited 2019 Jan 31]. 38 p. Available from: http://www.familycareintl.org/UserFiles/ File/Skilled Care Info Kit PDFs/English/Information Booklet_English. pdf

20. Oladapo OT, Daniel OJ, Olatunji AO. Knowledge and use of the partograph among healthcare personnel at the peripheral maternity centres in Nigeria. J Obstet Gynaecol (Lahore). 2006;26(6):538-41.

21. Fawole AO, Hunyinbo KI, Adekanle DA. Knowledge and utilization of the partograph among obstetric care givers in south west Nigeria. Afr Reprod Health. 2008;12(1):22-29.

22. Fawole AO, Adekanle DA, Hunyinbo KI. Utilization of the partograph in primary health care facilities in southwestern Nigeria. Niger J Clin Pract. 2010;13(2):200-4.

23. Bulatao RA, Ross JA. Which health services reduce maternal mortality? Evidence from ratings of maternal health services. Trop Med Int Health. 2003;8(8):710-21.

24. Ariff S, Soofi SB, Sadiq K, Feroze AB, Khan S, Jafarey SN, et al. Evaluation of health workforce competence in maternal and neonatal issues in public health sector of Pakistan: an assessment of their training needs. BMC Health Serv Res. 2010;10(319):1-9. 